\title{
TWO APPROACHES TO EXAMINE THE IMPACT OF DIFFERENT CREDIT DEFAULT INDICATORS ON REAL ESTATE LOANS
}

\author{
Reimar PFALZ \\ University of Latvia, Riga, Latvia \\ Corresponding author e-mail: plc_rem_fm@yahoo.com
}

\begin{abstract}
Financing of real estates was a trigger of the largest financial crisis after the "Great Depression" from the early thirties in the last century. One of the main causes of this 2007 crisis was poor risk management in real estate financing. The aim of this paper is to examine the impact of different classes of indicators on credit default rates of real estate loans. Two research approaches should confirm a model that proves how strong the relationship is between different predictor variables such as interest rates, macroeconomic and individual indicators on the response variable of credit defaults. The first approach focuses on conducting descriptive and inferential experimental research by collecting secondary data in different markets and by analysing these data for correlations and linear regressions. The second approach is an expert survey of different banks to compare and complement the results of the first research approach. The research provides the evidence that individual indicators and macroeconomic indicators have a higher impact on credit defaults than interest rates. The scientific research on this theme has led to nearly the same results in different markets: the unemployment rate and thus personal conditions are the most responsible predictors for the credit defaults, also in different markets. The novelty of the present research is the proof that a banking survey with primary data on the causes of credit defaults confirms and complements the results of the secondary data analysis.
\end{abstract}

Keywords: Credit Default, Credit Risk Management, Financial Crisis, Financing Real Estate, Interest Rate, Mortgage, Securitization, Subprime Mortgage Crisis

\section{INTRODUCTION}

The Topicality of the Research. Risk management came into the field of high interest because of the biggest worldwide financial crisis in the 1930s due to a lack of guidance and supervision in lending money for home mortgages (Brunnermeier, 2009). It seemed that the policy of giving mortgages under very mild conditions and at very low initial interest rates led to this disastrous situation of extreme increase of credit defaults especially in the USA real estate market (Mazumder \& Ahmad, 2010).

The topic is up to date even ten years after the crisis that started in 2007 because new findings and improvements of risk management for real estate financing are necessary at all times to protect the stakeholders from a financial crisis like this last one. 
The research object is risk management for the process of financing real estates.

The research subjects are defaulted mortgage loans of private residential real estates.

The aim of the research is to investigate and compare the impact of different classes of indicators as causes for credit defaults of private residential mortgages.

The methodology is aimed at ascertaining answers to three research questions and checking two central hypotheses about the causes for credit defaults. Therefore, two research approaches are used that should confirm a model that proves how strong the relationship is between different predictor variables such as mortgage interest rates, macroeconomic and individual indicators on the response variable of credit defaults. The first research approach focuses on conducting descriptive and inferential experimental research by collecting secondary data in different markets and by analysing these data for correlations and linear regressions by using statistical analyses, e.g., with XLSTAT ${ }^{\circledR}$ for Microsoft Excel ${ }^{\circledR}$. The second research approach, conducted with a banking survey, uses primary data to analyse the impact of interest rates and macroeconomic indicators on credit defaults, supplemented by borrower indicators. The research includes and is partly based on theoretical findings and empirical results of the research by the following paper (Pfalz, 2018), and is a continuation of the research.

The limitations are given by the research about financing private real estates with mortgages in the markets of the USA and Germany especially for the time period between 1998 and 2014. Commercial financing of real estates or other than the named markets or time periods are not the subject of the research.

\section{FINANCIAL RISK MANAGEMENT}

\subsection{Types of Risks}

As it has been found previously (Pfalz, 2018), in the view of the topic "financing residential real estates" it is helpful to use the New Oxford American Dictionary which defines "risk" as "a situation involving exposure to danger" or in economic terms "the possibility of financial loss" (Stevenson, 2016).

The aim of financial risk management for the system of mortgage lending should be to organize a situation for borrowers and lenders in which they are comfortable with their risks in financing. The main task of risk management is the diagnosis of the recent and future risks and the decision which risks are acceptable or which risks have to be managed by the organization (Hull, 2011).

Risk Management is a row of processes shown in Table 1, which contains Risk Identification, Risk Measurement, Risk Analysis, Risk Handling, and Risk Controlling. These processes run dynamically. At the beginning of the risk management process, a financial corporation has to identify the potential risks of the company. The next step is to measure and analyse the outcomes of the risk. At the end of these two stages, the enterprise knows its risks and the financial value of vulnerability. The next process is to decide how to handle the risks. Therefore, a strategy has to be developed that clarifies, which instruments should treat the risks. Depending on the risk aversion of the corporation, there are different methods to 
minimize or to avoid the risks, but there will not be a complete risk avoidance without the minimization or elimination of returns, too (Maier, 2007). Afterwards, the kind of risk handling is defined, the implementation of the strategy has to be organized, done, and controlled (Pfalz, 2018).

Table 1. Process of Financial Risk-Management (developed by the author on the basis of Wolke, 2008)

\begin{tabular}{llll}
\hline $\begin{array}{l}\text { Risk } \\
\text { Identification }\end{array}$ & $\begin{array}{l}\text { Risk Measurement } \\
\text { Risk Analysis }\end{array}$ & $\begin{array}{l}\text { Risk } \\
\text { Handling }\end{array}$ & $\begin{array}{l}\text { Risk } \\
\text { Controlling }\end{array}$ \\
\hline Types of Risks & Business Ratios & Instruments & Organization \\
\hline - Market Risks & - Expected Loss & - Prevention & - Planning \\
- Credit Risks & - Worst Case Loss & - Limitation & - Doing \\
- Liquidity Risks & - Value at Risk & - Compensation & - Control \\
- Operational Risks & - Volatility & - Diversification & - Action \\
& & & - Information \\
\hline
\end{tabular}

This paper is concerned especially with Credit Default Risks and uses quantitative and qualitative Risk Measurement and Risk Analysis as research methods. Quantitative methods of risk measurement are based on the determination of risk ratios. These are discovered by measurement of countable data of real estate financing and by using these data at stochastic equations to describe the risks (Pfalz, 2018). Banking survey is used as qualitative Risk Measurement and Risk Analysis.

Credit Risks are the Credit Default Risk, the Interest Rate Risk, or the PrePayment Risk. In this paper, only the Credit Default Risk will be estimated.

\subsection{Types of Mortgages}

According to the previous research (Pfalz, 2018), one of the most important financial decisions any household has to make is whether to own a home and, if so, how to finance it, and, depending on the fixedness of the interest rate during the contractual time, there are two broad categories of housing finance: Fixed (Interest) Rate Mortgages (FRM) and Adjustable (Interest) Rate Mortgages (ARM).

Fixed Rate Mortgages have the same interest rate about the whole time of the mortgage contract. Usual contract times are 10, 15, 20, or 30 years. The longer the borrower is willing to have the time for repaying the loan (maturity time), the higher the interest rate set by the lender due to a growing interest rate risk for the lender.

Adjustable Rate Mortgages have, in contrast to the fixed rate mortgages, a periodical change or adjustment of the interest rates during the time of repaying the loan. This adjustment could be done with shorter or longer intervals depending on the contract conditions. In the USA, the adjustment depends on the change of the interest rate (Federal Refund Rate) set by the central bank (US Federal Reserve Bank). The shorter the contractual time for checking and adjusting the interest rates, the smaller the interest rates for the borrower because of a smaller interest rate risk for the lender. In general, at the same time, the interest rates for ARM are lower than those for FRM due to a lower inherent interest rate risk for the lender.

A study by Mills and Gardner from 1986 showed that the majority of the customers preferred more riskless fixed rate mortgages than the ARM (Mills \& 
Gardner, 1986). In 2008, Bucks and Pence also described the adjustable rate mortgages, especially the part of the subprime adjustable rate mortgages, as more complicated than fixed rate mortgages (Bucks \& Pence, 2008).

\subsection{Credit Defaults and Foreclosures}

The Credit Default Risk is highly related to the default risk of the borrowers in case of being unwilling or unable to repay a loan (Pfalz, 2018). This kind of risk was the most important of all risks as a trigger of the financial crisis.

Causes for credit defaults of the borrowers can be changes in interest rates (adjustable rate mortgages), or in individual indicators or macroeconomic indicators. Adverse movements in macroeconomic factors can potentially affect borrower's ability to pay and it threatens a foreclosure. Foreclosure means that the property rights go from the borrower to the lender, so the lender has the right to sell the property to use the money for its losses from payments. It is necessary for lenders to understand the relationship between macroeconomic indicators and credit default risk and foreclosures in order to manage this risk (Nang, Neo, \& Ong, 2003).

\section{RESEARCH DESIGN AND METHODOLOGY}

The research design builds the frame for the collection and analysis of data. A special aim of the research design is, e.g., to express causal connections between numbers of variables (Bryman \& Bell, 2007). The so-called cross-sectional design is used. It means that the same variables will be analysed at different groups or inside this paper at different markets. Another name for this cross-cultural or international research is comparative research design (Bryman \& Bell, 2007).

Furthermore, a quantitative research strategy is used. It means the researcher sets at first the theory or creates at first a model and then proves it by data collection and analysis. It is also called the deductive approach (Collis \& Hussey, 2009). Primary and secondary data are taken for the analysis. There can be cross-sectional measurements at one point of time or there can be measurements over a time horizon, which are called time series measurements followed by a time series analysis (Schulze \& Porath, 2012). Time series between 1998 and 2014 are used as data material for correlation and regression analyses within this paper. Memmel et al. stated that the advantage of using observable average data as systematic drivers is that one can use standard econometric tools such as linear regressions (Memmel, Gündüz, \& Raupach, 2015).

Fig. 1 shows the research model for credit defaults. This research model has one response variable, which is the credit default, and three categories of predictor variables, the interest rates, the macroeconomic indicators and the individual indicators. Each of these categories has some sub-categories. 


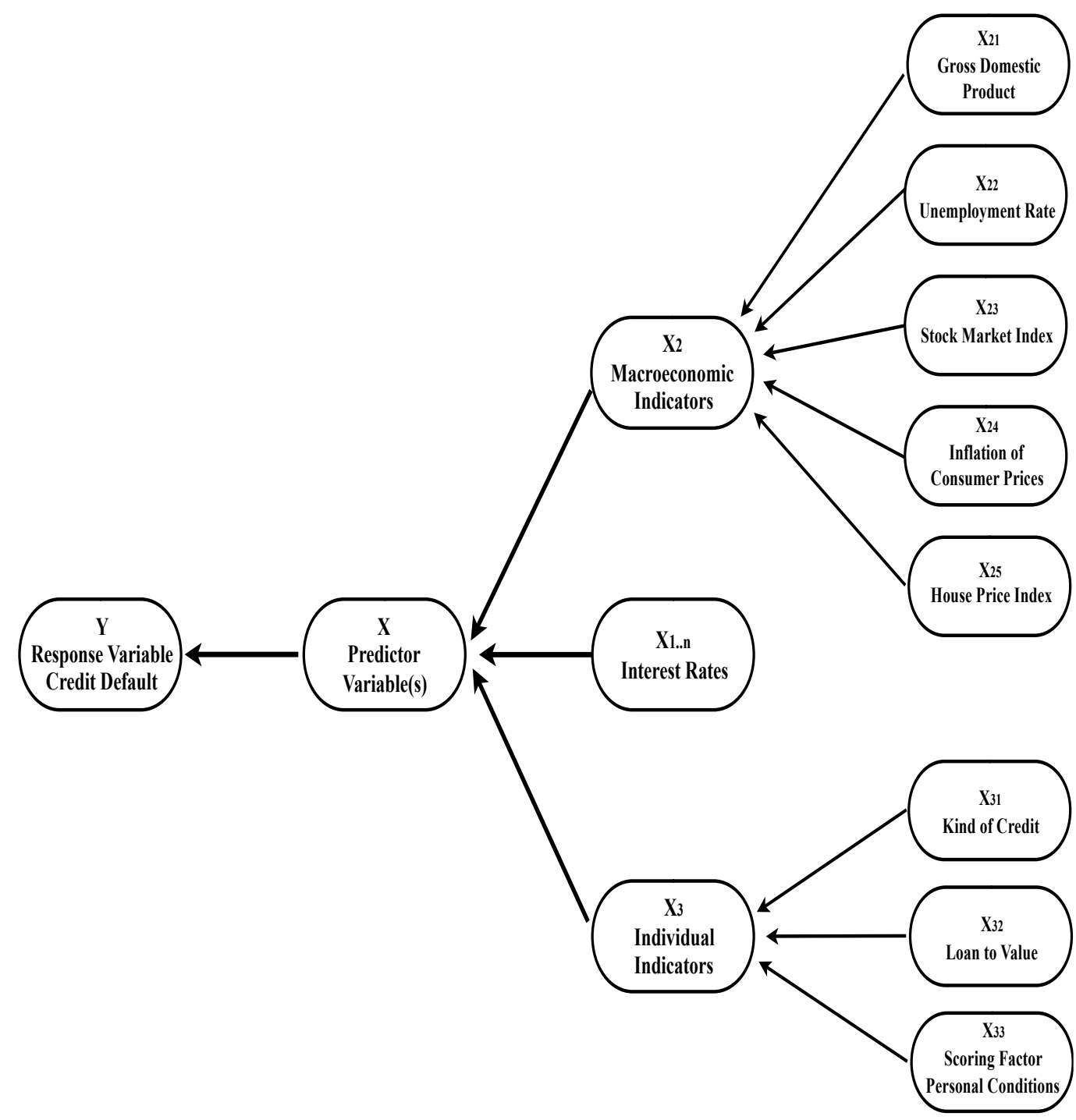

Fig. 1. Research model for credit defaults (developed by the author).

For this relationship model, the following different types of interest rates for different types of mortgages are chosen: adjustable rate mortgages (ARM) and fixed rate mortgages (FRM), and the following macroeconomic indicators: Gross Domestic Product, House or Home Price Indexes, Unemployment Rate, Stock Exchange Rates, and Consumer Price Index. On the side of the individual indicators, the following variables are selected: the individual scoring factors, individual conditions, individually chosen type of mortgage (FRM or ARM), and the loan-to-value ratio.

Levišauskaite and Varanauskine see household income, housing prices, inflation and interest rates for stability of loans as the most important factors for credit defaults (Levišauskaite \& Varanauskine, 2013). Rottke and Gentgen wrote that the gross domestic product and the unemployment rate were the strongest macroeconomic factors with the most implications not only on the German real 
estate market (Rottke \& Gentgen, 2008). Diaz-Serrano found that the volatility of household income also triggered, e.g., from the employment status and other unforeseen events was the most relevant variable that influenced mortgage delinquencies (Diaz-Serrano, 2005). Danis and Pennington-Cross also stated that the probability of default was strongly related to the local labor market conditions, which was represented by the unemployment rate (Danis \& Pennington-Cross, 2008).

Three research questions have been set within the framework of the present research:

$\mathbf{R Q}_{1}$ Which influences do the interest rates have on the credit default rates?

$\mathbf{R Q}_{2}$ Which influences do macroeconomic indicators have on the credit defaults?

$\mathbf{R Q}_{3}$ Which influences do individual indicators have on the credit default rates?

The first research approach investigates the indicators for the credit defaults from secondary data and uses correlation and bivariate linear regression. The method of correlation and linear regression analysis is the most widely used model to explain statistical relationships. In the first research approach, two central hypotheses are investigated to compare the influences of interest rates and of macroeconomic factors on the credit defaults.

$\mathbf{H}_{01}$ the credit default rates of mortgages are not significantly dependent on the interest rates of these mortgages.

$\mathbf{H}_{02}$ the credit default rates of mortgages are significantly dependent on the main macroeconomic indicators.

Both hypotheses are tested by correlations and bivariate linear regressions because only one dependent and one independent variable are to be compared. They are tested in the USA and the German market by the same way and using the same predictors mentioned above.

The second research approach is a bank survey from 2019 with risk management experts from eleven German financial institutions to demonstrate the validation or negation of the results from the first approach. The first part of the survey was concerned with collecting data about the financial institutions: name of the institution, name and job position of the expert and the shareholder structure of the financial institution (private, cooperative or public). The second part gathered data about the types of mortgages offered by the bank. What were the credit default rates for ARM and FRM?

The third part of the survey contained a lot of questions about the financial institutions' statements:

- to the development of credit defaults during 2007 and 2010;

- to the main factors for credit defaults: macroeconomic indicators, level of 
interest rates and personal situation of the borrower;

- to macroeconomic indicators for credit defaults as a change in gross domestic product, unemployment rate, inflation rate of consumer prices, stock market index and house price index;

- to which extent the financial institution considers macroeconomic indicators;

- to borrower indicators for credit defaults: type of the chosen mortgage, loan-tovalue ratio of the loan, scoring-factor of the borrower;

- to which extent the financial institution considers borrower indicators;

- to which extent the financial institution considers borrowers' scoring;

- to the financial institutions' behaviour in case of a credit default: prolongation of the maturity time, start foreclosure process.

For the evaluation of the questions above, the experts were asked to state whether they agreed with each statement. Therefore, it is recommended to use the so-called five-point Likert scale with a range from strongly disagree (1) to strongly agree (5) (Babbie, 1990). Raab-Steiner and Benesch wrote that data obtained from a 5-point Likert scale can be treated as continuous data during statistical analysis (Raab-Steiner \& Benesch, 2012). Moreover, Babbie recommended using a fivepoint Likert scale, if the respondent was able to give a short answer within a questionnaire (Babbie, 1990). Further on, there are open questions, where the respondents should write about things like other macroeconomic indicators for credit defaults, other borrower indicators for credit defaults, or other types of financial institutions' behaviour in case of customers credit default. The questions of the fourth part of the questionnaire are concerned with the risk management practice of the financial institutions:

- Which method do you see as the most efficient measurement of financial risks from credit defaults?

- How do you measure financial risks, using the Value-at-Risk model or other measurements?

- Which types of problems in terms of real estate mortgages do you see for risk management at your financial institution?

- How does your financial institution manage risks from credit defaults?

Knowing that written surveys offer many benefits, the impersonality of the method can be a disadvantage and requires clear instructions to prevent the answers from being erroneous (see Mathur \& Evans, 2005). For this reason, the written survey was tested in advance with experts from the University of Latvia, the Technical University Rosenheim (Germany) and the Bavarian Bankers Association. The statistical calculation is performed by examining the answers to normal distribution with the Kolmogorov-Smirnov test. The Kolmogorov-Smirnov test is a very useful nonparametric test of the equality of one-dimensional probability distributions that can be used to compare a sample with a reference probability (Hedderich \& Sachs, 2016). 


\section{ANALYSIS OF THE MARKETS}

The analysis of the markets is an empirical investigation of Risk Identification. One cause of this large crisis was the huge part of Adjustable Rate Mortgages (ARM) in the USA market. The number of ARM had a steep increase in the USA market between 2001 and 2004 from $12 \%$ up to $34 \%$. The 2008 default rate of subprime ARM was $33.4 \%$ vs. $3.0 \%$ of prime FRM. The number of the subprime borrowers in the USA increased from 2001 to 2005 from 7.8 up to $21.3 \%$ (Barth, 2009). From 2007 to 2013, more than 5.5 million families in the USA lost their homes due to foreclosures during the repossession process.

More than 11 million borrowers around $23 \%$ of households with mortgages got in trouble with their mortgages (Das, 2012). At least during 2007 and 2014 more than 15.5 million USA households had to open a foreclosure filing in the foreclosure process because of not fulfilling their financial duties to the banks (Statista, 2015).

In Figures Fig. 2 and Fig. 3, one can see the development of the average interest rates and the credit default rates during the research period between 1998 and 2014.

It is apparent that the average interest rates followed nearly the same course: the highest value in 2000, decreasing until 2005 then increasing in the USA until 2006, in Germany until 2008 and then both markets had the decreasing interest rates until the end of the research period.

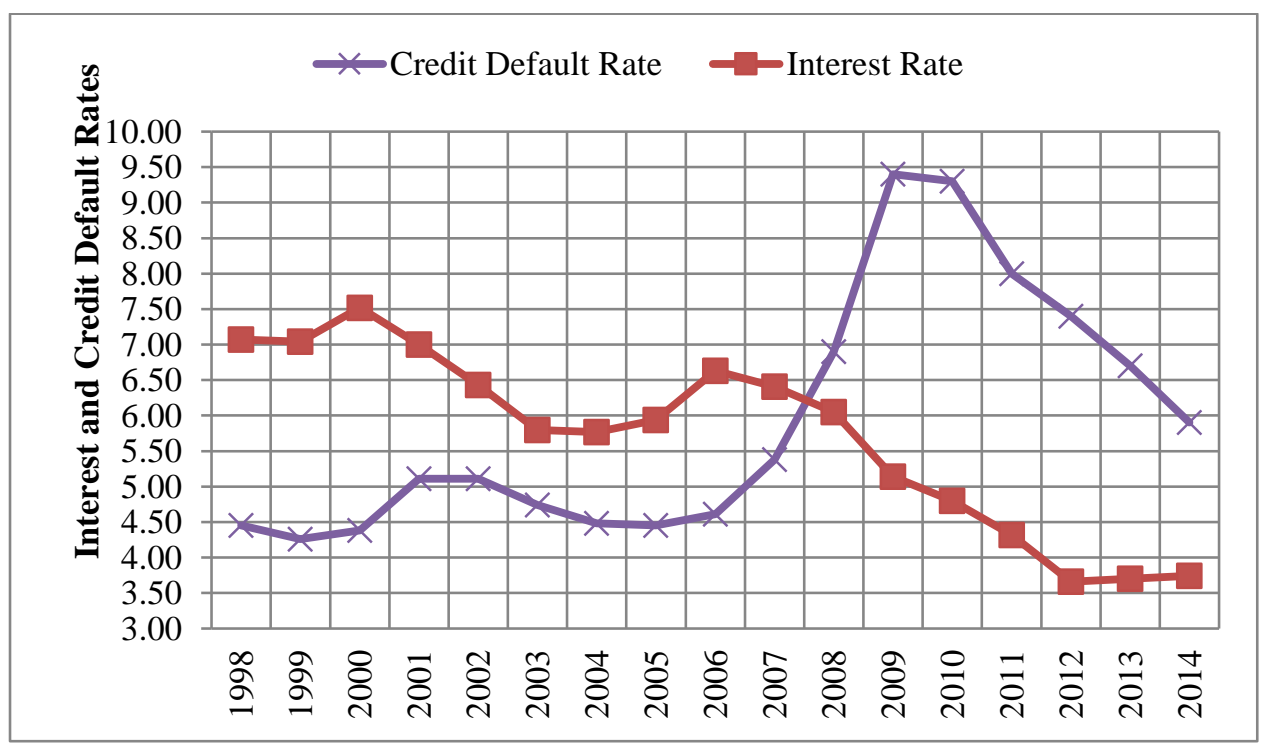

Fig. 2. The interest and credit default rates in the USA, 1998-2014 (developed by the author, based on data by Statista 2016).

During the research period, both markets had the lowest credit default rates around the year 2000, the time before the dotcom-crisis. After the crisis, a slow increase followed until 2002 in both markets. Then, the credit default rates were shrinking also in both markets: in Germany until the end of the research period, but in the USA only until 2005/2006, the point where the subprime crisis had its 
beginning with a sharp increase of credit defaults until 2009/2010 when the crisis calmed down again.

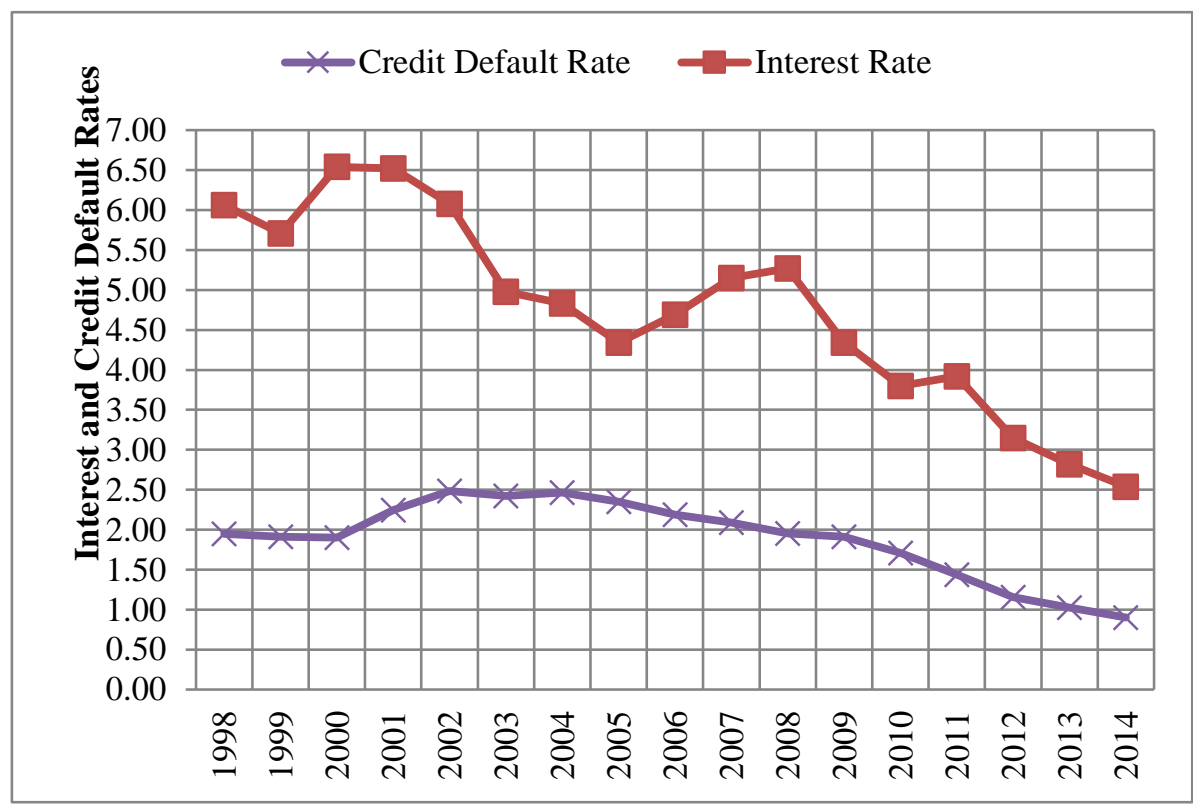

Fig. 3. The interest and credit default rates in Germany, 1998-2014 (developed by the author, based on data by Statista 2016).

During the phase, when the USA market had its worst time with credit defaults, the German default rates of mortgages were very stable on a low level. Since 2004, the delinquency rates of mortgages have been shrinking continuously from around $2.5 \%$ to $0.9 \%$ in 2014 (see Fig. 3). In general, the credit default rates in Germany were much smaller than in the USA during "normal" time periods.

\section{RESEARCH FINDINGS}

\subsection{Findings for the First Research Approach}

In Table 2, one can see directly the differences between the both markets. The coefficient of determination $R^{2}$ demonstrates the strength of the regression function. The larger the $R^{2}$, the better the goodness of fit. The hypothesis is proven when the $p$-value is smaller than the set value for the significance level; in this paper it is 0.05 .

One interesting fact is that apart from the unemployment rate (UER), all variables are in another way correlated with the credit default rate in the USA and Germany. In the author's opinion, the German correlations have the "right" directions. It means that good macroeconomic values are related to low credit default rates and vice versa.

The American correlations look like a "wrong" working market. The meaning of "right" and "wrong" in the case of how the markets are working is common sense as well as the scientific view that good macroeconomic conditions lead to low credit defaults and vice versa - bad macroeconomic conditions lead to high credit default rates. 
Table 2. Comparison of Hypotheses-Tests in the USA and Germany (developed by the author)

\begin{tabular}{|c|c|c|c|c|c|c|}
\hline & \multicolumn{3}{|c|}{ The USA Market } & \multicolumn{3}{|c|}{ The German Market } \\
\hline Hypothesis & $R^{2}$ & $p$-Value & Correlation & $R^{2}$ & $p$-Value & Correlation \\
\hline $\mathrm{H}_{01}$-AIR & 0.425 & 0.005 & -0.652 & 0.536 & 0.001 & 0.732 \\
\hline $\mathrm{H}_{01}-\mathrm{FRM}$ & 0.331 & 0.016 & -0.575 & - & - & - \\
\hline $\mathrm{H}_{01}$-ARM & 0.226 & 0.054 & -0.475 & - & - & - \\
\hline $\mathrm{H}_{02}$-GDP & 0.415 & $0 ., 005$ & 0.644 & 0.416 & 0.005 & -0.645 \\
\hline $\mathrm{H}_{02}$-UER & 0.875 & $<0.0001$ & 0.935 & 0.808 & $<0.0001$ & 0.899 \\
\hline H02-DJIA, DAX & 0.025 & 0.543 & 0.159 & 0.670 & $<0.0001$ & -0.819 \\
\hline $\mathrm{H}_{02}$-ICP & 0.212 & 0.063 & -0.460 & 0.001 & 0.900 & 0.033 \\
\hline $\mathrm{H}_{02}$-HPI & 0.020 & 0.589 & 0.141 & 0.763 & $<0.0001$ & -0.874 \\
\hline
\end{tabular}

Test of Hol-Hypothesis (Interest Rates) in the USA market:

Average of Interest Rates for Mortgages (AIR)

- Ho1-us-AIR was rejected. (The hypothesis was not proven.)

- Credit defaults are significantly dependent on mortgages with Average Interest Rates

Fixed (Interest-) Rate Mortgages (FRM)

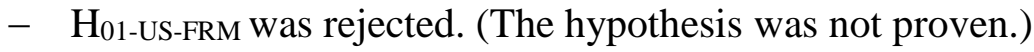

- Credit defaults are significantly dependent on Fixed Rate Mortgages

Adjustable (Interest-) Rate Mortgages (ARM)

- Ho1-US-ARM was accepted. (The hypothesis was proven.)

- Credit defaults are not significantly dependent on Adjustable Rate Mortgages

Test of $\mathrm{H}_{01}$-Hypothesis (Interest Rates) in the German market:

Average of Interest Rates for Mortgages (AIR)

- H01-DE-AIR was rejected. (The hypothesis was not proven.)

- Credit defaults are significantly dependent on mortgages with Average Interest Rates

Test of $\mathrm{H}_{02}$-Hypotheses (Macroeconomic Indicators) in the USA market:

Gross Domestic Product (GDP)

- H02-US-GDP was accepted. (The hypothesis was proven.)

- Credit defaults are significantly dependent on the Gross Domestic Product. 


\section{Unemployment Rate (UER)}

- $\mathrm{H}_{02-\text {-Us-UER was accepted. (The hypothesis was proven.) }}$

- Credit defaults are significantly dependent on the Unemployment Rates. Stock Market Index: DJIA

- Ho2-us-DJIA was rejected. (The hypothesis was not proven.)

- Credit defaults are not significantly dependent on the stock market index: DJIA.

Inflation of Consumer Prices (ICP)

- $\mathrm{H}_{02-\text { US-ICP }}$ was rejected. (The hypothesis was not proven.)

- Credit defaults are not significantly dependent on the Inflation of Consumer Prices.

Case Shiller Home Price Index (HPI)

- Ho2-Us-HPI was rejected. (The hypothesis was not proven.)

- Credit defaults are not significantly dependent on the Case Shiller House Price Index.

Test of $\mathrm{H}_{02}$-Hypotheses (Macroeconomic Indicators) in the German market:

\section{Gross Domestic Product (GDP)}

- H02-DE-GDP was accepted. (The hypothesis was proven.)

- Credit defaults are significantly dependent on the Gross Domestic Product.

Unemployment Rate (UER)

- $\mathrm{H}_{02-\mathrm{DE}-U E R}$ was accepted. (The hypothesis was proven.)

- Credit defaults are significantly dependent on the Unemployment Rates.

\section{Stock Market Index: DAX}

- H02-DE-DAX was accepted. (The hypothesis was proven.)

- Credit defaults are significantly dependent on the stock market index: DAX.

Inflation of Consumer Prices (ICP)

- $\mathrm{H}_{02-\mathrm{DE}-\mathrm{ICP}}$ was rejected. (The hypothesis was not proven.)

- Credit defaults are not significantly dependent on the Inflation of Consumer Prices.

\section{Home Price Index (HPI)}

- H02-DE-HPI was accepted. (The hypothesis was proven.)

- Credit defaults are significantly dependent on the House Price Index.

Fig. 4 and Fig. 5 demonstrate graphically the research results as relationship models for the USA and German markets. Only those indicators are statistically relevant as predictors for credit defaults, which show the coefficient of determination $\left(R^{2}\right)$. 


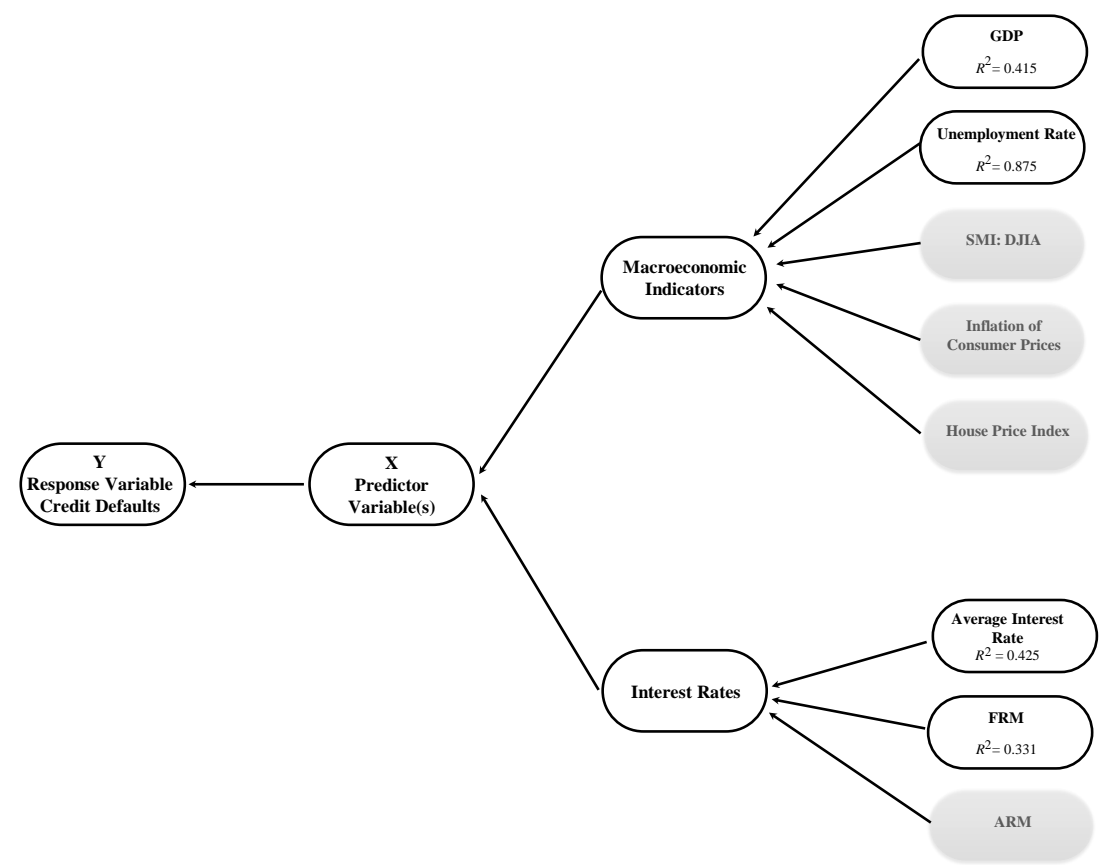

Fig. 4. The model of results for the USA market (developed by the author).

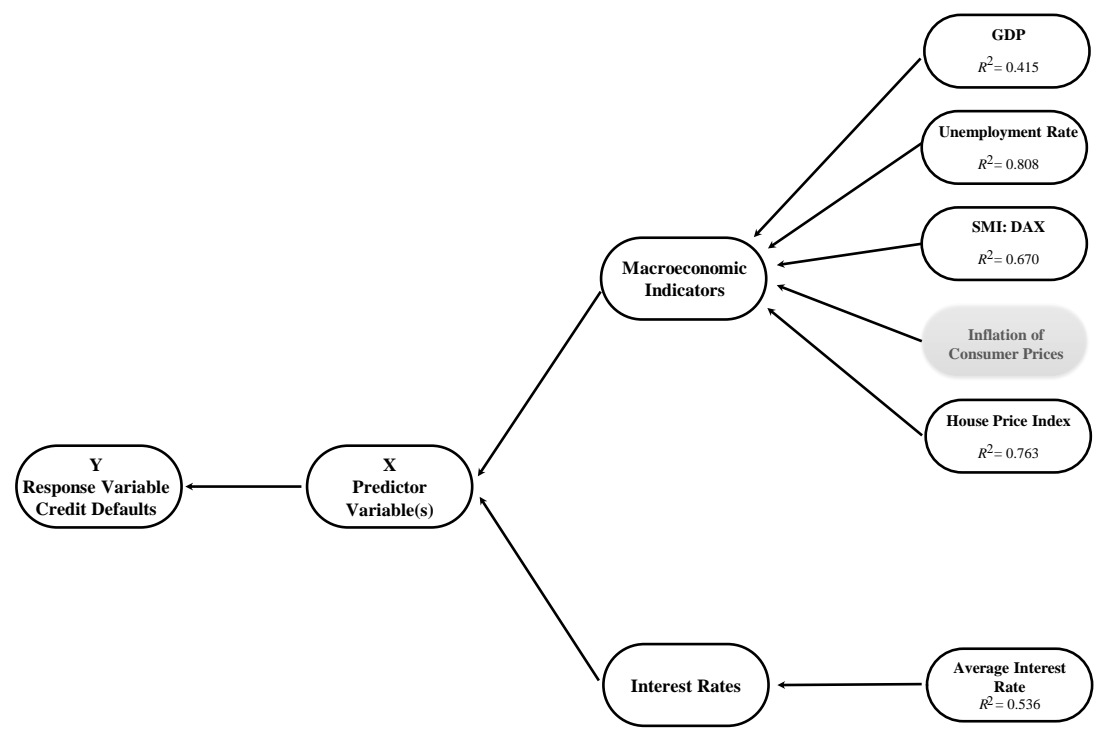

Fig. 5. The model of results for the German Market (developed by the author). 
The main findings of the first research approach for RQ1 are as follows:

- The average interest rates of the mortgages have a significant influence on the credit defaults in both the USA and German markets.

- The influence of the fixed rate mortgages is more significant than that of the average interest rate mortgages on credit defaults in the USA market, and the adjusted rate mortgages have no significant influence on credit defaults in the USA.

The main findings of the first research approach for RQ2 are as follows:

- The unemployment rate is the macroeconomic indicator with the most significant influence on the credit defaults in both markets.

- The order of the following macroeconomic significant indicators for credit defaults in the German market is home price index, stock market index and gross domestic product.

- The gross domestic product has the second place of macroeconomic indicators with significant influence on the credit defaults in the USA.

- The inflation of consumer prices has no significant influence on credit defaults either in the USA or in Germany.

Finding of the second research approach are described further.

\subsection{Findings for the Second Research Approach}

At first, the examination with the Kolmogorov-Smirnov test resulted in a normal distribution for all the questions. It means all answers can be used for the survey.

Respondents of the bank survey were asked to comment on the most responsible factor for credit losses: macroeconomic indicators, level of interest rates or personal situations of the borrower (see Table 3).

Table 3. The Major Factors for Credit Defaults (developed by the author)

\begin{tabular}{|l|l|l|l|l|}
\hline $\begin{array}{l}\text { Expert of } \\
\text { Financial } \\
\text { Institution } \\
\text { (FI) }\end{array}$ & $\begin{array}{l}\text { 6. Factors for } \\
\text { CD }\end{array}$ & $\begin{array}{l}\text { 6.1. } \\
\text { Macroeconomic } \\
\text { Indicators }\end{array}$ & $\begin{array}{l}\text { 6.2. Levels of } \\
\text { Interest Rates }\end{array}$ & $\begin{array}{l}\text { 6.3. Personal } \\
\text { Situations of the } \\
\text { Borrower }\end{array}$ \\
\hline Expert FI 1 & & 4 & 4 & 5 \\
\hline Expert FI 2 & & 5 & 4 & 5 \\
\hline Expert FI 3 & & 5 & 5 & 5 \\
\hline Expert FI 4 & & 5 & 3 & 5 \\
\hline Expert FI 5 & & 4 & 4 & 4 \\
\hline Expert FI 6 & & 4 & 2 & 5 \\
\hline Expert FI 7 & & 4 & 3 & 4 \\
\hline Expert FI 8 & & 4 & 3 & 4 \\
\hline Expert FI 9 & & 4 & 3 & 4 \\
\hline Expert FI 10 & & 5 & 4 & 5 \\
\hline Expert FI 11 & & 4 & & 4 \\
\hline & & $\mathbf{3 . 5 4 5}$ & $\mathbf{4 . 5 4 5}$ \\
\hline & & $\mathbf{4 . 3 6 4}$ & \\
\hline Mean & & & & \\
\hline
\end{tabular}


The answers in Table 3 show that the financial institutions perceive the personal situation of the borrowers (mean 4.545) as the most responsible factor for credit defaults followed by macroeconomic indicators (mean 4.364). As the factor with the lowest influence on credit defaults, they see the level of interest rates (mean 3.545).

Table 4 is related to the macroeconomic indicators as factors for credit defaults. It is evident from Table 4 that the unemployment rate (mean 4.545) is seen by the financial institutions as the most responsible macroeconomic indicator for credit defaults followed by a clear difference of one point by gross domestic product (mean 3.545) and house price index (mean 3.545). Stock market index (mean 3.273) and inflation rate of consumer prices (mean 3.182) have an average value as an answer to this question.

This order of answers seems rational. The unemployment rate is the most important macroeconomic factor, as it is well known that people have great difficulties repaying mortgages when they lose the job. The next place is taken by the gross domestic product and the house price index together because they are also closely related to credit defaults of real estate loans, but on a lower level than the unemployment rate.

Table 4. Macroeconomic Indicators for Credit Defaults (developed by the author)

\begin{tabular}{|l|l|l|l|l|l|l|}
\hline $\begin{array}{l}\text { Expert of } \\
\text { Financial } \\
\text { Institution } \\
\text { (FI) }\end{array}$ & $\begin{array}{l}\mathbf{7 . 1 .} \\
\text { Gross } \\
\text { Domestic } \\
\text { Product }\end{array}$ & $\begin{array}{l}\mathbf{7 . 2 .} \\
\text { Unemploy } \\
\text { ment Rate }\end{array}$ & $\begin{array}{l}\text { 7.3. Inflation } \\
\text { Rate of } \\
\text { Consumer } \\
\text { Prices }\end{array}$ & $\begin{array}{l}\text { 7.4. Stock } \\
\text { market } \\
\text { index }\end{array}$ & $\begin{array}{l}\text { 7.5. } \\
\text { House } \\
\text { Price } \\
\text { Index }\end{array}$ & $\begin{array}{l}\text { 8. To which } \\
\text { extent your FI } \\
\text { considers } \\
\text { Macroeconom } \\
\text { ic Indicators } \\
\text { for RM }\end{array}$ \\
\hline Expert FI 1 & 4 & 4 & 3 & 4 & 4 & 4 \\
\hline Expert FI 2 & 4 & 5 & 3 & 3 & 3 & 4 \\
\hline Expert FI 3 & 3 & 5 & 5 & 4 & 4 & 5 \\
\hline Expert FI 4 & 3 & 4 & 4 & 4 & 3 & 4 \\
\hline Expert FI 5 & 3 & 4 & 3 & 3 & 4 & 3 \\
\hline Expert FI 6 & 4 & 5 & 3 & 2 & 3 & 3 \\
\hline Expert FI 7 & 3 & 4 & 2 & 3 & 4 & 3 \\
\hline Expert FI 8 & 5 & 4 & 3 & 2 & 3 & 4 \\
\hline Expert FI 9 & 4 & 5 & 3 & 3 & 3 & 4 \\
\hline Expert FI 10 & 2 & 5 & 2 & 4 & 4 & 3 \\
\hline Expert FI 11 & 4 & 5 & 4 & 4 & 4 & 4 \\
\hline & & & & & & \\
\hline & & & & & & \\
\hline Mean & $\mathbf{3 . 5 4 5}$ & $\mathbf{4 . 5 4 5}$ & $\mathbf{3 . 1 8 2}$ & $\mathbf{3 . 2 7 3}$ & $\mathbf{3 . 5 4 5}$ & $\mathbf{3 . 7 2 7}$ \\
\hline
\end{tabular}

Concerning the borrower indicators, the scoring factor of the borrower (mean 4.364 ) is of high importance for the banks (see Table 5). With a gap of more than one point, the type of chosen mortgage (mean 3.273) and the loan-to-value ratio (mean 3.273) follow together. These variables are of average importance to financial institutions. In general, the experts answered that borrower indicators (mean 4.364) and especially the borrowers' scoring (mean 4.273) had a great importance in their banks' risk management. 
Table 5. Borrower Indicators for Credit Defaults (developed by the author)

\begin{tabular}{|l|l|l|l|l|l|}
\hline $\begin{array}{l}\text { Expert of } \\
\text { Financial } \\
\text { institution } \\
\text { (FI) }\end{array}$ & $\begin{array}{l}\text { 9.1. Type of } \\
\text { chosen } \\
\text { Mortgage }\end{array}$ & $\begin{array}{l}\text { 9.2. Loan to } \\
\text { value ratio }\end{array}$ & $\begin{array}{l}\text { 9.3. Scoring } \\
\text { factor of the } \\
\text { borrower }\end{array}$ & $\begin{array}{l}\text { 10. to which } \\
\text { extent your } \\
\text { FI considers } \\
\text { Borrower } \\
\text { Indicators } \\
\text { for RM }\end{array}$ & $\begin{array}{l}\text { 11. to which } \\
\text { extent your } \\
\text { FI considers } \\
\text { Borrower`s } \\
\text { Scoring for } \\
\text { RM }\end{array}$ \\
\hline Expert FI 1 & 4 & 4 & 4 & 4 & 4 \\
\hline Expert FI 2 & 1 & 4 & 5 & 5 & 5 \\
\hline Expert FI 3 & 5 & 2 & 5 & 4 & 5 \\
\hline Expert FI 4 & 4 & 3 & 5 & 5 & 4 \\
\hline Expert FI 5 & 3 & 2 & 4 & 4 & 4 \\
\hline Expert FI 6 & 4 & 4 & 4 & 5 & 4 \\
\hline Expert FI 7 & 3 & 3 & 4 & 3 & 4 \\
\hline Expert FI 8 & 3 & 4 & 5 & 5 & 4 \\
\hline Expert FI 9 & 4 & 3 & 4 & 4 & 5 \\
\hline Expert FI 10 & 2 & 3 & 4 & 5 & 4 \\
\hline Expert FI 11 & 3 & 4 & 4 & 4 & \\
\hline & & & & & $\mathbf{4 . 2 7 3}$ \\
\hline & $\mathbf{3 . 2 7 3}$ & $\mathbf{3 . 2 7 3}$ & $\mathbf{4 . 3 6 4}$ & $\mathbf{4 . 3 6 4}$ \\
\hline Mean & & & \\
\hline
\end{tabular}

If a loan defaults, the German financial institutions rather prefer a hard foreclosure process (mean 4.000) for a defaulted loan than a prolongation of the credit maturity time (mean 2.273). This behaviour is only possible because there is a high probability of selling houses from foreclosure processes with good results. Related to the bank risk management, nine of the eleven institutions questioned perceived the Value-at-Risk Model as the most effective one. A further result is that $91 \%$ of the banks use a risk management model, and the use of the VaR model by $82 \%$ of the investigated German financial institutions is a great success. Furthermore, more than $50 \%$ of the banks do not see relevant problems with their real estate loans. It is a sign for an unproblematic German real estate market. Nearly $40 \%$ of the financial institutions see problems, especially when borrowers come in trouble with repayment of the loans mostly caused by changing their personal family status.

Fig. 6 presents the graphical overview of the results of the banking survey.

The main findings of the second research approach for RQ1 are as follows:

- The influence of the level of interest rates of the mortgages on the credit defaults is clearly existent with a mean of 3.545. This is behind the personal situations of borrowers and behind the macroeconomic indicators.

The main findings of the second research approach for RQ2 are as follows:

- The influence of the macroeconomic indicators on the credit defaults is high with a mean of 4.364 . This is only behind personal situations of borrowers.

- The unemployment rate is that macroeconomic indicator with the most significant influence on the credit defaults with a mean of 4.545 .

- The order of the following macroeconomic indicators for credit defaults in the German market is home price index (mean 3.545), gross domestic product (mean 3.545), stock market index (mean 3.273), and at least inflation of consumer prices (mean 3.182). 


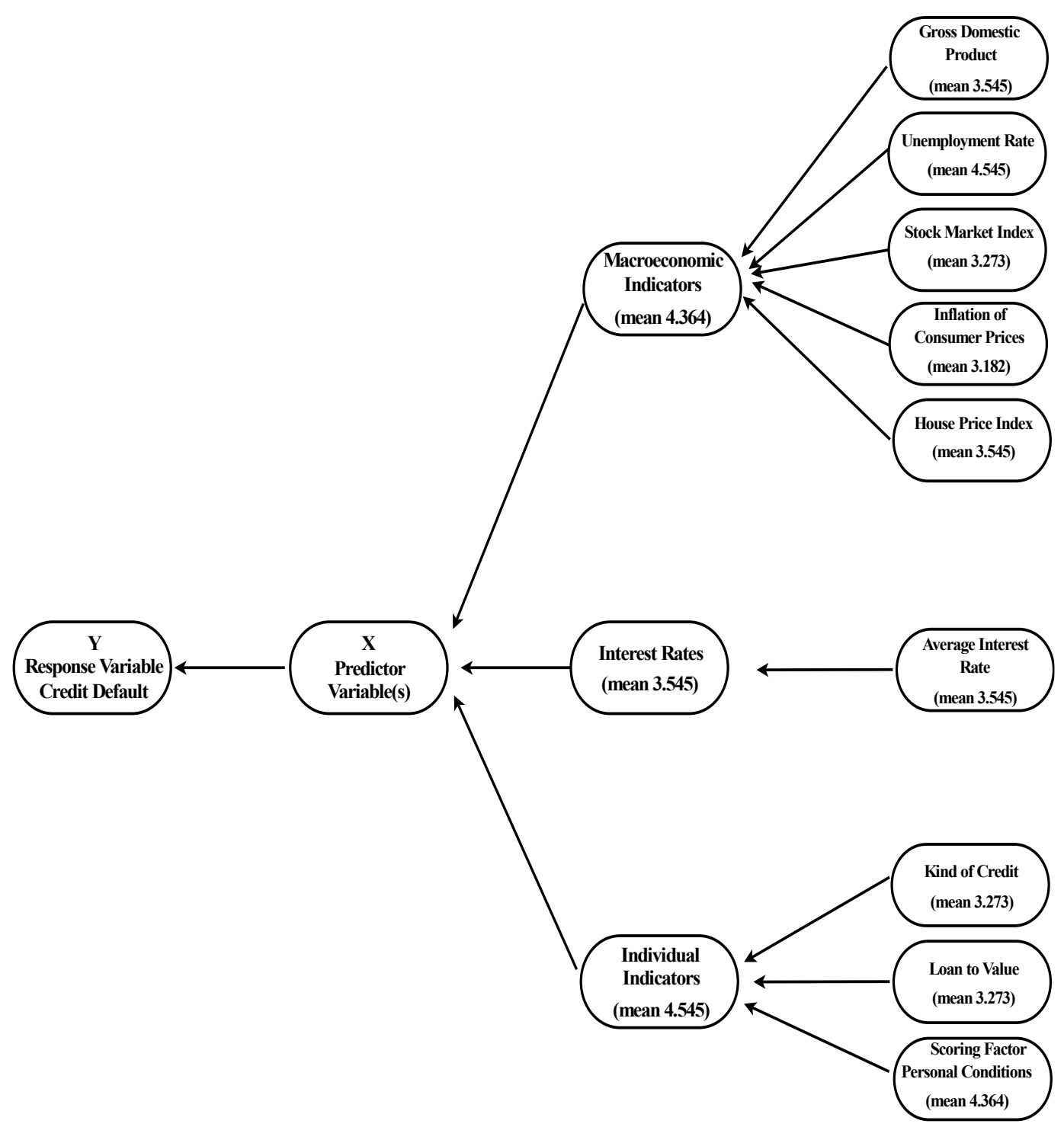

Fig. 6. Results of bank survey for the German market (developed by the author).

The main findings of the second research approach for RQ3 are as follows:

- The personal situation of the borrower has the largest influence on the credit defaults with a mean of 4.545 .

- The scoring factor of the borrower is that borrower indicator with the most significant influence on the credit defaults with a mean of 4.364 , which is followed by the type of chosen mortgage and loan-to-value ratio, both with a mean of 3.273. 


\section{CONCLUSION}

1. The research model (Fig. 1) is confirmed by both research approaches. The results of the first and second research approaches essentially coincide. Interest rates, macroeconomic and individual indicators have an influence on credit defaults!

2. The novelty of this paper and the main finding of the research are the evidence that interest rates are not the catalyst for credit defaults. These are individual indicators such as the personal situation and the scoring of the borrowers, as well as the key macroeconomic indicators, such as the unemployment rate.

3. The subprime mortgage crisis of 2007-2010 was a result of what would happen if there were an immense failing of risk management (Pfalz, 2018). None of the four phases of risk management, which were described, did work effectively before and during the crisis, especially in the USA market. Risk Identification. At first, the risks with subprime loans were not identified correctly and the loss of diligence to check borrowers' credit worthiness before giving loans was a massive fault and led to a massive misidentification of the risks. The examination of the borrower's credit worthiness is an extremely necessary point to prevent such huge numbers of credit defaults. In this point, the markets of the USA and Germany worked completely divergent. Such a strict check of the borrowers' credit worthiness in Germany stands in connection with very small loan defaults is also confirmed by the results of the expert survey of the financial institutions. Risk Measurement and Analysis have to be enhanced as well by improving the risk management models, such as the value at risk model, which was used before, during and after the crisis. Risk Handling before this crisis was very careless and partially fraudulent in the USA market because it was not only a question of fairness to sell unchecked mortgages in the second mortgage market, but it was also a question of fraud and, therefore, should be corrected immediately. Risk Controlling has gone wrong on the part of all stakeholders: from the lenders' part, to the internal and external controlling of financial institutions and furthermore to the governmental part.

4. The Financial Crisis Inquiry Commission of the US Representative House concluded in their final report from 2011 that this crisis was avoidable. The author confirms this statement and adds: It would be avoidable by just a simple risk management method: checking of the borrowers' credit worthiness! This is the most necessary recommendation to all lending institutions.

\section{REFERENCES}

Babbie, E. R. (1990). Survey Research Methods (2nd ed.). Belmont, Calif: Cengage Learning.

Barth, J. R. (2009). The Rise and Fall of the U.S. Mortgage and Credit Markets: A Comprehensive Analysis of the Market Meltdown. Hoboken, N.J.: Wiley.

Brunnermeier, M. K. (2009). Deciphering the Liquidity and Credit Crunch 2007-08. SSRN Electronic Journal, 23. https://doi.org/10.2139/ssrn.1317454

Bryman, A., \& Bell, E. (2007). Business research methods (2nd ed.). Oxford: Oxford University Press. 
Bucks, B., \& Pence, K. (2008). Do borrowers know their mortgage terms? Journal of Urban Economics, 64(2), 218-233. https://doi.org/10.1016/j.jue.2008.07.005

Collis, J., \& Hussey, R. (2009). Business research: A practical guide for undergraduate \& postgraduate students (3rd ed.). Hampshire, [UK] ; New York, NY: Palgrave Macmillan.

Danis, M. A., \& Pennington-Cross, A. (2008). The delinquency of subprime mortgages. Financing Community Reinvestment and Development, 60(1-2), 67-90. https://doi.org/10.1016/j.jeconbus.2007.08.005

Das, S. R. (2012). The Principal Principle. Journal of Financial \& Quantitative Analysis, 47(6), 1215-1246. https://doi.org/10.1017/S0022109012000506

Diaz-Serrano, L. (2005). Income volatility and residential mortgage delinquency across the EU. International Mortgage Markets, 14(3), 153-177. https://doi.org/10.1016/j.jhe.2005.07.003

Hedderich, J., \& Sachs, L. (2016). Angewandte Statistik: Methodensammlung mit R (15., überarbeitete und erweiterte Auflage). Berlin Heidelberg: Springer Spektrum. https://doi.org/10.1007/978-3-662-45691-0

Hull, J. (2011). Risikomanagement Banken, Versicherungen und andere Finanzinstitutionen (2., aktualisierte Aufl.). München: Pearson Studium.

Levišauskaite, K., \& Varanauskine, J. (2013). Macroeconomic factors' influence on mortgage interest rate type demand. Makroekonominiu Veiksniu Itaka Būsto Paskolu Palūkanu Normu Rūšies Paklausai, 7(2), 101-112. https://doi.org/10.7220/AESR.1822.7996.2013.7.2.7

Maier, K. M. (2007). Risikomanagement im Immobilien- und Finanzierungswesen: Ein Leitfaden für Theorie und Praxis (3.). Frankfurt: Fritz Knapp Verlag.

Mathur, A., \& Evans, J. R. (2005). The value of online surveys. Internet Research, 15(2), 195-219. https://doi.org/10.1108/10662240510590360

Mazumder, M. I., \& Ahmad, N. (2010). Greed, financial innovation or laxity of regulation? A close look into the 2007-2009 financial crisis and stock market volatility. Studies in Economics and Finance, 27(2), 110-134. https://doi.org/10.1108/10867371011048616

Memmel, C., Gündüz, Y., \& Raupach, P. (2015). The common drivers of default risk. Journal of Financial Stability, 16, 232-247. https://doi.org/10.1016/j.jfs.2014.03.002

Mills, D. L., \& Gardner, M. J. (1986). Consumer Response to Adjustable Rate Mortgages: Implications of the Evidence from Illinois and Wisconsin. Journal of Consumer Affairs, 20(1), 77. https://doi.org/10.1111/j.1745-6606.1986.tb00369.x

Nang, P. Y., Neo, P. H., \& Ong, S. E. (2003). Macro-economic factors and foreclosure risk: Evidence from mortgages in Singapore. Journal of Property Investment \& Finance, 21(6), 411434. https://doi.org/10.1108/14635780310508603

Pfalz, R. (2018). Management of Credit Default Indicators in private Real Estate Financing. Riga Technical University 59th International Scientific Conference "Scientific Conference on Economics and Entrepreneurship" (SCEE'2018) Proceedings, 80-90. Riga, Latvia: RTU.

Raab-Steiner, E., \& Benesch, M. (2012). Der Fragebogen: Von der Forschungsidee zur SPSS/PASW Auswertung. UTB GmbH.

Rottke, N. B., \& Gentgen, J. (2008). Workout management of non-performing loans: A formal model based on transaction cost economics. Journal of Property Investment \& Finance, 26(1), 59-79. https://doi.org/10.1108/14635780810845163

Schulze, P. M., \& Porath, D. (2012). Statistik mit Datenanalyse und ökonometrischen Grundlagen (7., überarb. und erw. Aufl). München: Oldenbourg. https://doi.org/10.1515/9783486718478

Statista (2015). Number of U.S. properties with foreclosure filings 2014 | Statistic. Retrieved May 15, 2015, from Statista website: http://www.statista.com/statistics/381400/housing-units-withforeclosure-filings-usa/

Statista. (2016). Kreditaufnahme und Verschuldung - Statista-Dossier | Statista. Retrieved October 6, 2016, from https://de.statista.com/statistik/studie/id/6688/dokument/kreditaufnahme-undverschuldung-statista-dossier/

Stevenson. (2016). Risk-Definition of risk in English from the Oxford dictionary. Retrieved May 27, 2016, from http://www.oxforddictionaries.com/definition/english/risk

Wolke, T. (2008). Risikomanagement (2., vollst. überarb. u. erw. Aufl.). München: Oldenbourg. https://doi.org/10.1524/9783486592542 


\section{THE AUTHOR' SHORT BIOGRAPHY}

Reimar Pfalz is a Doctoral Student at the Faculty of Business, Management and Economics of the University of Latvia, Riga. He received a degree of Master of Arts in Real Estate Management from the Business School of the University of Applied Sciences in Kufstein (Austria) in 2010 and a Diploma of Engineer in Building Construction from the University of Applied Sciences in Magdeburg (Germany) in 1990. In 2010, he earned a scholarship from the International Facility Management Association (Houston, the USA). In 2009, he earned a Best Student Award from the Austrian state. Since 2000, he has been working for a Bavarian town as the Head of the Real Estate Department. Before, he worked as an Architect at several architectural offices. His current research field is financial risk management for financing real estates.

Address: Reimar Pfalz, Höglweg 6, 85540 Haar, Germany.

E-mail: plc_rem_fm@yahoo.com 


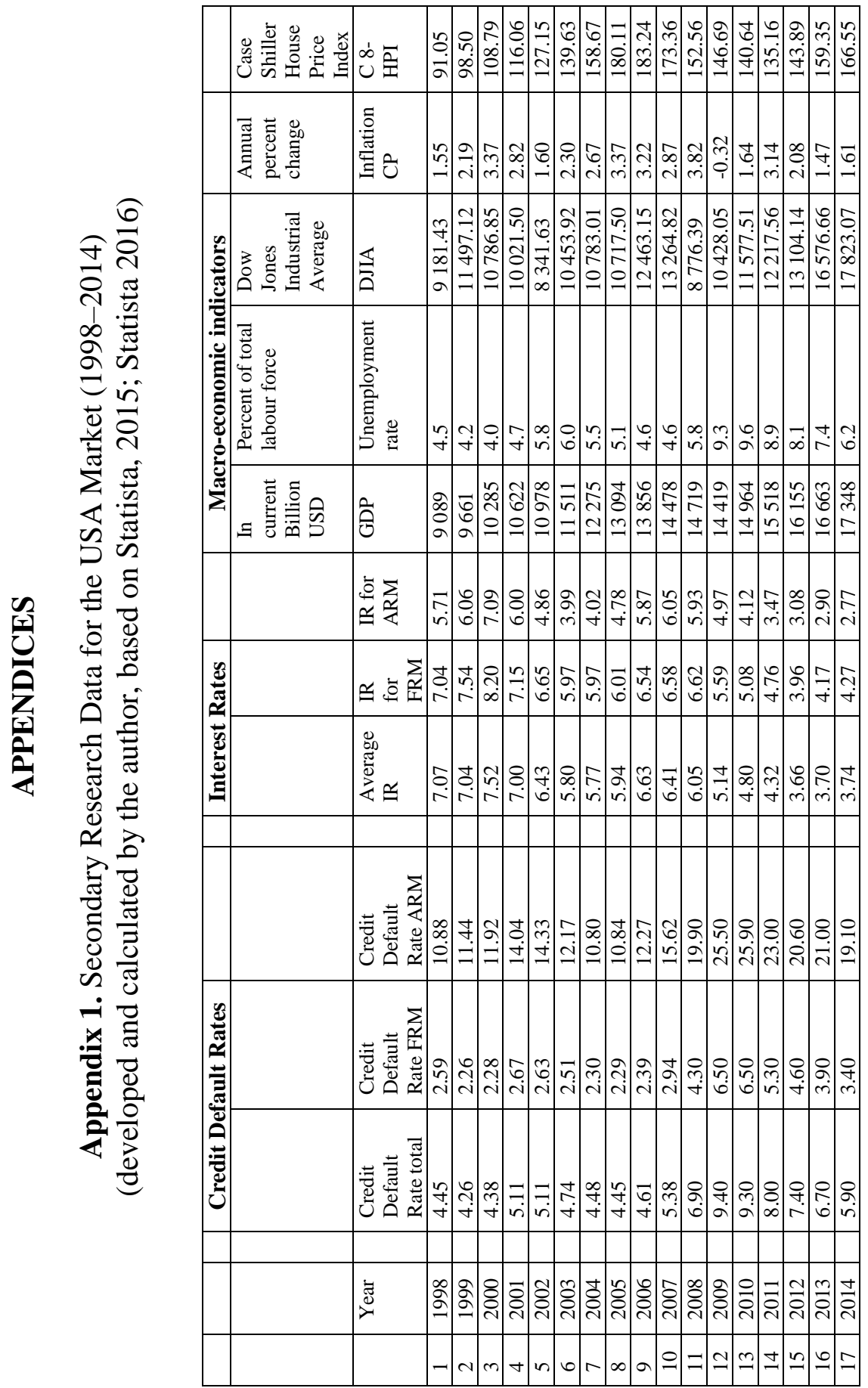




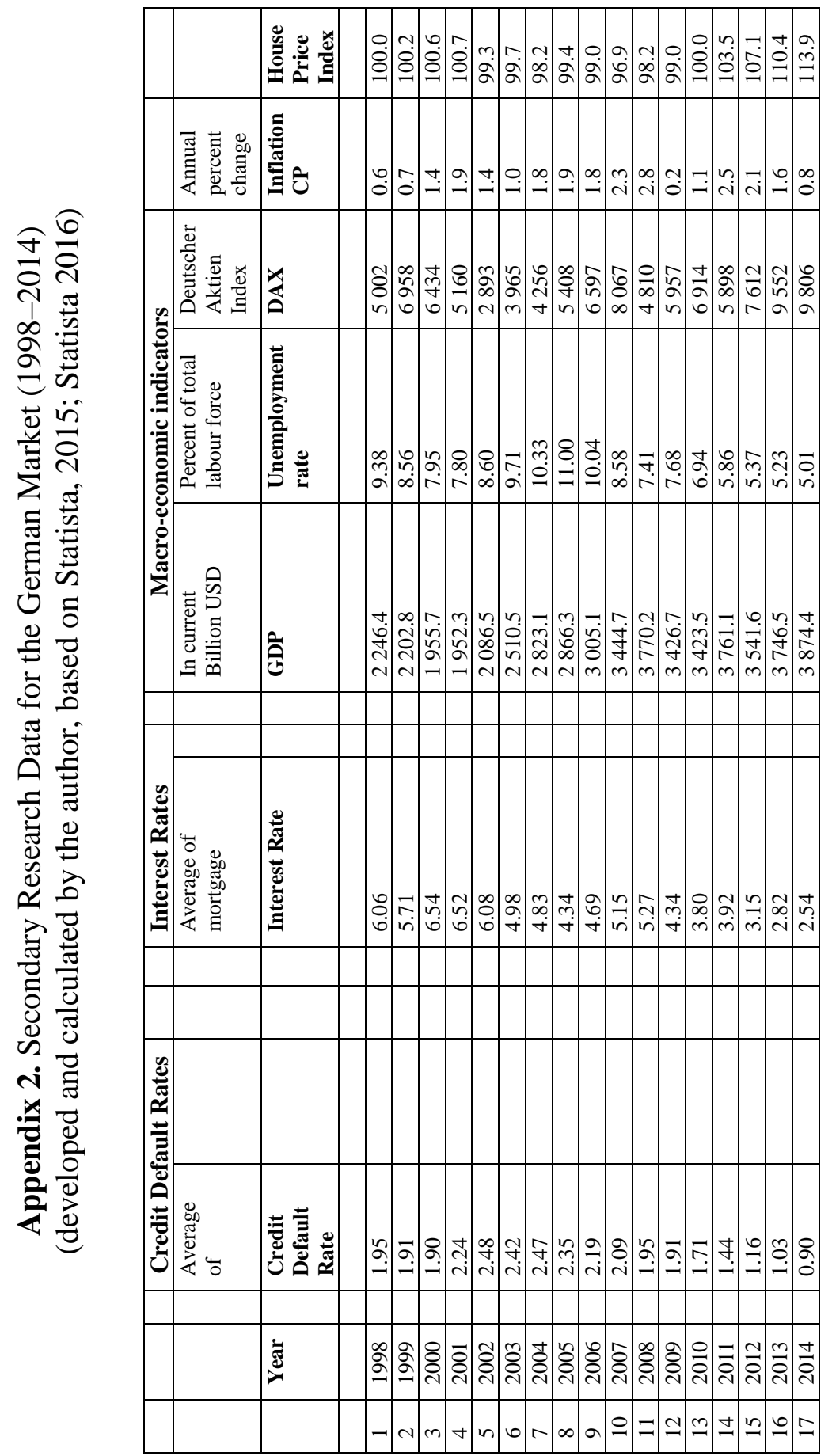




\section{Appendix 3. Blank Copy of the Assessment for the Bank Survey}

Dear survey participant,

My name is Reimar Pfalz. I am a doctoral student at the Faculty of Business, Management and Economics of the University of Latvia in Riga. Thank you very much for supporting my research survey that I use for my Doctoral Thesis about financial risk management. The theme of the Thesis is:

\section{“Credit Default Indicators in Private Real Estate Financing”}

The goal of the expert survey is to assess:

- what indicators for credit defaults are relevant for financial institutions;

- how financial institutions evaluate the indicators for credit defaults at private real estate financing institution;

- how financial institutions manage the risks of financial losses from credit defaults.

The research study focuses on the major German financial institutions.

Upon study completion, each participating financial institution will receive a report of the research results, while survey results are only reported in the aggregate to safeguard the anonymity of the participants.

The time requirement for questionnaire administration is approximately 15 minutes.

Please send me your survey results by e-mail to: plc_rem_fm@yahoo.com

Thank you very much for dedicating time in study participation!

Reimar Pfalz

Master of Arts in Business

Mobile: + 49 (0) 15756630067

E-Mail: plc_rem_fm@yahoo.com

\begin{tabular}{|l|l|}
\hline Name of the financial institution: & \\
\hline Name of the risk management expert: & \\
\hline Job position of the expert: & \\
\hline
\end{tabular}

1. Shareholder structure of your financial institution:

Private Bank $\square$

Public-law Bank

Cooperative Bank $\square$

2. What types of real estate mortgages does your financial institution sell?

Fixed (interest) rate mortgages $\square$ Since (year): ..
Adjustable (interest) rate mortgages $\square$ Since (year): ... 
3. What was the part in percent of the mortgages during last three years?

For fixed rate mortgages (FRM): ...

For adjustable rate mortgages (ARM): ...

4. What was the average in percent of the credit default rate during last three years?

For fixed rate mortgages: ...

For adjustable rate mortgages: ...

5. What was the development trend of the credit default rates at your financial institution during the financial crisis between 2007 and 2010?

For FRM:

strongly descending $\square \quad$ descending $\square \quad$ no change $\square \quad$ ascending $\square \quad$ strongly ascending $\square$

For ARM:

strongly descending $\square \quad$ descending $\square \quad$ no change $\square \quad$ ascending $\square \quad$ strongly ascending $\square$

6. Which factors do you analyze as indicators for credit defaults?

- Macroeconomic indicators

strongly disagree $\square$ disagree $\square$ neither / nor $\square$ somewhat agree $\square$ strongly agree $\square$

- $\quad$ Level of interest rates

strongly disagree $\square$ disagree $\square$ neither / nor $\square$ somewhat agree $\square$ strongly agree $\square$

- Personal situation of the borrower

strongly disagree $\square$ disagree $\square$ neither / nor $\square$ somewhat agree $\square$ strongly agree $\square$

- $\quad$ Do you pay attention to other factors? To which ones?

7. Which of the following macroeconomic indicators do you see as a possible trigger for credit defaults? 
- Change in the gross domestic product

strongly disagree $\square$ disagree $\square$ neither / nor $\square$ somewhat agree $\square$ strongly agree $\square$

- $\quad$ Change in the unemployment rate

strongly disagree $\square$ disagree $\square$ neither / nor $\square$ somewhat agree $\square$ strongly agree $\square$

- $\quad$ Change in the inflation of consumer prices

strongly disagree $\square$ disagree $\square$ neither / nor $\square$ somewhat agree $\square$ strongly agree $\square$

- $\quad$ Change in the stock market index (DAX)

strongly disagree $\square$ disagree $\square$ neither / nor $\square$ somewhat agree $\square$ strongly agree $\square$

- $\quad$ Change in the house price index

strongly disagree $\square$ disagree $\square$ neither / nor $\square$ somewhat agree $\square$ strongly agree $\square$

- Do you see other economic indicators as a trigger for credit defaults? Which ones?

8. To which extent do you consider macroeconomic indicators to manage your risks from credit defaults?

not at all $\square \quad$ little $\square \quad$ somewhat $\square \quad$ a lot $\square \quad$ very much $\square$

9. Which of the following indicators of the borrowers do you see as a possible trigger for credit defaults?

- $\quad$ Type of the chosen mortgage (ARM or FRM)

strongly disagree $\square$ disagree $\square$ neither / nor $\square$ somewhat agree $\square$ strongly agree $\square$

- $\quad$ Loan-to-value ratio of the mortgage

strongly disagree $\square$ disagree $\square$ neither / nor $\square$ somewhat agree $\square$ strongly agree $\square$

- Scoring factor of the borrower

strongly disagree $\square$ disagree $\square$ neither / nor $\square$ somewhat agree $\square$ strongly agree $\square$

- Do you pay attention to other borrower indicators? To which ones?

10. To which extent do you consider indicators of the borrowers to manage the risks from credit defaults? 


not at all $\square \quad$ little $\square \quad$ somewhat $\square \quad$ a lot $\square \quad$ very much $\square$

11. To which extent do you consider the scoring factor of the borrowers to prevent your institution from credit default risks?

not at all $\square \quad$ little $\square \quad$ somewhat $\square \quad$ a lot $\square \quad$ very much $\square$

12. What is your institutions behavior in case of a looming credit default of a borrower?

- $\quad$ Prolongation of the maturity time by decreasing the mortgage interest rate strongly disagree $\square$ disagree $\square$ neither / nor $\square$ somewhat agree $\square$ strongly agree $\square$

- Back settlement of the credit and foreclosure of the object

strongly disagree $\square$ disagree $\square$ neither / nor $\square$ somewhat agree $\square$ strongly agree $\square$

- Do you pay attention to other solutions? To which ones?

13. Which method do you see as the most efficient measurement of financial risks from credit defaults?

14. How do you measure financial risks at your financial institution?

- $\quad$ Using the Value-at-Risk Model by CreditMetrics: $\quad$ yes $\square \quad$ no $\square$

- Using other models? Which ones?

15. Which types of problems from real estate mortgages do you see for the risk management at your financial institution? 
16. How does your financial institution manage risks from credit defaults?

Thank you very much for participation in the survey! 